\title{
Transformation of Public Administration Mechanisms: Experience of Uzbekistan
}

\author{
Muminov Alisher Gaffarovich, Mavlonov Djurabek Yorkulovich, Sokiev Khurshid Valievich, \\ Turgunov Azim Turgunovich
}

\begin{abstract}
Experts in the field of political research believe that computerization and the emergence of branched information systems require further improvement of the communication foundations of interaction between the subjects of the political process. This seems to be one of the strategic directions in the development of modern democracy. The growing interest in the field of political communications in social research is due to the fact that the development of political communications has significant potential for further democratization of socio-political institutions and processes in modern society. This article discusses the issues of transformation of the public administration system in Uzbekistan, the formation of effective mechanisms of "Electronic Government", the existing problems and prospects for the development of this sphere in Uzbekistan
\end{abstract}

Keywords: information, globalization, technics, technology, cultural, democracy, strategy, civil society.

\section{INTRODUCTION}

Nowadays, the public information capacity and status have become the most important and necessary factor in the formulation and implementation of countries development strategy. Intense globalization processes have increased the relevance of issues related to the use of electronic communications in public administration. Indeed, information is the source of power in modern society, and the level of access of state power to modern technics, technology and communication systems is a very important factor in determining the effectiveness of government. At the same time, as a result of the development of information technologies, the major institutions of society, such as governments, healthcare, family and marriage, culture, education and science are undergoing a serious transformation. Leading experts in the field of political research believe that computerization and the emergence of branched information systems require further improvement of the communication foundations of interaction between the subjects of the political process.

Revised Manuscript Received on December 30, 2019.

* Correspondence Author

Muminov Alisher Gaffarovich, professor, Doctor of political sciences, National University of Uzbekistan elyor_1988@yahoo.com. ORCid: 0000-0003-0463-5436

Mavlonov Djurabek Yorkulovich, associate professor, Doctor of political sciences, National University of Uzbekistan, gmavlonov@rambler.ru. ORCid.org: 0000-0001-5957-1279

Sokiev Khurshid Valievich, Doctoral candidate ( $\mathrm{PhD}$ ), National University of Uzbekistan, khurshidik@gmail.com. ORCid: 0000-0002-7985-9162

Turgunov Azim Turgunovich, senior lecturer, National University of Uzbekistan.

(C) The Authors. Published by Blue Eyes Intelligence Engineering and Sciences Publication (BEIESP). This is an open access article under the CC BY-NC-ND license (http://creativecommons.org/licenses/by-nc-nd/4.0/)
This seems to be one of the strategic directions in the development of modern democracy. The growing interest in the field of political communications in social research is due to the fact that the development of political communications has significant potential for further

democratization of socio-political institutions and processes in modern society[1].

The most important indicator of a democratic society in the world is the provision of dialogue between the state and citizens, and the existence of mechanisms to optimize the interaction of public authorities with public organizations. This implies the development by the scientific community of effective methods and technologies for organizing political communication. Therefore, today a number of scientific centers conduct research aimed at further enhancing the effectiveness of the dialogue between civil society institutions and public authorities in order to solve pressing socio-economic problems.

Changes in the information space of modern society lead to the formation of a new system of values, the newest priorities of knowledge and practice. Such values and priorities have a significant impact on human behavior in society, the development of political and economic systems, and the functioning of almost all institutions.

Thus, the culture of information-provided society forms a new type of power - power based on scientific knowledge. Such power is an essential and inseparable feature of the information society, indicating the directions and parameters of its political, economic, cultural and social development.

It should be noted that today, based on the development of information technologies, the form and content of the activities of state authorities are cardinally changed and new procedures of democratic governance are formed and improved.

In a changing information environment, the interaction of state and society is becoming a new configuration - a digital partnership configuration. This provides an opportunity to upgrade the existing and traditional forms of citizen-to-government communication with government agencies, as well as the emergence of a qualitatively new type of interaction between governments - e-government and e-democracy[2]. The emergence of such interrelations means a radical re-examination of the values of public administration, the expertise of public authorities in an open democratic society that facilitates effective decision-making. 
Electronic democracy is at the beginning of its development, its potential is vast and widely debated all over the world, and theoretical consideration of e-democracy as a new phenomenon of culture is becoming increasingly important. The possibility of digital government, cyberpolicy, e-voting, digital democracy, and computer-based political communication is an indication of radical changes in the forms of political, economic and cultural mechanisms in the context of the information society. Mankind is approaching to a turning point of a cultural revolution. At the same time, power will be more qualified, more transparent and more effective, due to greater citizens' access to democratic procedures and greater participation in decision-making.

The state information policy will be implemented to address these tasks, as well as those that have a significant impact on the process of public administration system transformation.

In Uzbekistan, the implementation of such strategic tasks as the implementation of democratic reforms, the formation and strengthening of the political and legal consciousness of the population, increasing the activity of civil society, has become the agenda. A solid regulatory framework has been created for the consistent development of civil society, a multi-party system has been formed, the legal and political consciousness of citizens has radically changed, the self-governing body of citizens - makhalla has been recognized by the international community as a unique institution of civil society, and legal mechanisms have been created for the participation of public organizations in decision-making of national importance. Today in Uzbekistan, special attention is paid to the renewal of society, the development of broad democratic relations between the state and the people. That is why 2017 was declared the "Year of dialogue with the people and human interests" and the corresponding State program was adopted. This reinforces the relevance of the search for optimal ways and methods of improving the political dialogue, increasing the participation of civil society institutions on the basis of studying the best practices of leading countries of the world.

\section{RESEARCH METHODOLOGY}

For the study of the problem the methods of expert evaluation and documentation study and analysis were used. In particular, it is now fully understood that information is a national resource in Uzbekistan, and its preservation, development and wisely use are of national importance. Thus, at this stage the society information field is focused to develop and not only telecommunications, information systems or mass communications, and as well as processes associated with the creation, storage, processing, transmission and distribution of qualitatively new types of information (to be well-informed about business-oriented, audience oriented, scientific and educational news, etc.), and also the development of the concept of a unified state policy in the field of information, covering the whole set of relations[3].

Such concept includes in itself:

- society must be ready to use democratic mechanisms, and citizens must be ready to use their knowledge, time and efforts to participate in the governance process;
- the mechanisms of the political system to recognize and represent the interests of large social groups in a timely manner and to ensure mutual agreement between the public on these interests;

-being able to respond to the needs of society when power is becoming increasingly complex in the conditions of the "information age";

- availability of mechanisms for permanent and direct impact of democracy, effective communication channels, public control, communications and "two-way communication" in the increasing transition to qualitative political participation, civil self-government and control of citizens;

- first of all to submit draft laws, decisions, programs of all levels of state power to the general discussion of citizens, to evaluate the effectiveness of the existing laws and their implementation;

- such issues are covered as public administration to be understandable and easy to use for society through e-technologies.

On the basis of these, it is important to note that Uzbekistan, which is trying to occupy leading positions in the world community, is working on developing an effective national information policy. We can conclude that such a policy is a priority for radical reform of public administration in ensuring a transition to a democratic society.

There are many examples in our country today that show that the government is focusing its efforts on improving the quality of life of ordinary citizens through the provision of electronic services. Not only are government agencies at different levels integrated into the system, they are also working to adapt their work to that system, ensuring the co-operation between the various structures and bodies that make up the system and their full compliance. Such free and unmentionable access to and use of information on the state of affairs in the country naturally creates a need for citizens to participate regularly in politics and governance.

In this regard, the next practical solution to e-government in Uzbekistan is not only as a way to modernize existing structures and social relations, but it should be noted that it is also an independent idea of a comprehensive change of the principles of the organization of public administration.

In addition to the potential risks of information communications, information communications have the advantage of promoting democracy.. As an example of our country, this can be seen in wider involvement of people in resolution approving processes, enabling them to gain more complete control over the state. On the other hand, there is also the possibility of infringement on the right of having no connection with the privacy because of rapid development of information technology.

In this regard, Uzbekistan has, like many other countries, established and improved the legal framework and administrative regulations (effective mechanisms for protecting intellectual property[4], personal data[5], and privacy rights[6]) that meet the modern conditions of information communication; 
Conditions in the branches of information industry, investments in education system, development of free competition, international cooperation, provision of public services through electronic means are created for harmonization of efforts of various subjects of society.

Now, in our country, conditions are being created to stimulate direct communication between the authorities and the public in order to overcome the "lack of confidence in the government", the authorities themselves initiate such a dialogue. Specialized press services[7] for public relations are established in the government. They regularly inform society about the activities, plans and decisions of public authorities.

In this regard, taking into account the necessity of wide introduction of modern information and communication technologies into the system of state and social construction and in our daily life, it is necessary to emphasize the opinion of the President of the Republic of Uzbekistan Sh. Mirziyoyev, "Today, it is impossible to speak about modernization and renewal of the country, the achievement of sustainable development without extensive development of information and communication technologies, the Internet ..., we should consider the issue of a worthy place in the global information technology market as a priority.[8]

\section{RESULTS AND DISCUSSION}

At present, we are witnessing the emergence of entirely new mechanisms of public administration. For example, the implementation of the concept of "e-government" in Uzbekistan[9] is aimed at improving the quality of public services, systematic improvement of the efficiency of public authorities, and providing access to and access to information about the activities of public organizations and authorities at all levels of citizens. The interactive interface on the portals of public authorities creates conditions for a comprehensive reflection and broad discussion of plans and programs, and monitoring of their implementation. This transparency of information facilitates the direct communication of citizens with the public authorities through the use of information and communication technologies, participation of citizens in the discussion of managerial decisions and, ultimately, increased trust in the authorities.

It should be noted that the system of "electronic government" emerged as a concept of public administration between the XX and XXI centuries. Based on the values of modern information and communication technologies and civil society, it has become a priority for countries in the process of transitioning to an information society.

Due to the development of modern information and communication technologies, a comprehensive study of the transformation of public administration is important to study taking into account national features of this field. In this regard, it is important to analyze and introduce the positive experience of foreign experience in the transformation of public administration mechanisms in the process of informing the public in our country.

There are many examples in Uzbekistan that show that the government is focusing its efforts on improving the quality of life of ordinary citizens through the provision of electronic services. It should be noted that large-scale work in this area is carried out systematically in the country.
It should be noted that today the legal, institutional and organizational foundations of the "E-government" system have been established in the country[10]. Here are just a few examples.

Legal basis for the formation of the "E-government" system in Uzbekistan:

- It should be noted that the Law "On Transparency of Activities of State Authorities and Governments"[11], in recent years "About e-government"[12], "About social partnership"[13], The law "On appeals of individuals and legal officials"[14], "On Person Data"[15] ва "Tо the Criminal, Criminal Procedure Codes of the Republic of Uzbekistan "On introducing changes and amendments to the Administrative amenability Code of the Republic of Uzbekistan"[16] and adoption of other laws of the Republic of Uzbekistan can be considered as an example of attention to legal regulation of relations in the field of public administration in the country and wider involvement of the public in this process;

- Nearly twenty Decrees[17] and resolutions[18] of the President of the Republic of Uzbekistan over the last two or three years, resolutions[19] of the Cabinet of Ministers have further enhanced the effectiveness of ICT in public administration and public authorities and socio-economic spheres.

When we talk about these laws, it is worth noting the January 2019 Decree of the President of the Republic of Uzbekistan "On measures to further improving the system of dealing with population problems".[20]

According to it, the establishment of an open dialogue between the authorities and the public, identifying current problems, the Public Liaison Office, which has fully justified itself in practice, has become an effective mechanism for the legal and quality handling of appeals, and now coordinates all public service activities.

As the logical continuation of this event is the activities of regional offices of state bodies and regional branches of other organizations and the disciplines for their services are intended to ensure complete and quick delivery of information to the population through communication technologies, including mobile applications, websites, and electronic payment tools.

At the same time we can see in Fig 1. the task of establishing websites of regional offices of numerous government agencies and other organizations by july 1,2019 , websites of district and city divisions by january 1, 2020 will allow citizens to apply directly to territorial subdivisions of government agencies.[21]

\begin{tabular}{|l|l|l|l|}
\hline № & \multicolumn{1}{|c|}{ Organizations/centers } & year & basics \\
\hline 1. & The Government Portal & 2014 & {$[27]$.} \\
\hline 2. & $\begin{array}{l}\text { Ministry of Development of } \\
\text { Information Technologies and } \\
\text { Communications of the Republic } \\
\text { of Uzbekistan }\end{array}$ & [22] \\
\hline 3. & $\begin{array}{l}\text { An e-Government Development } \\
\text { Center }\end{array}$ & 2018 & [23] \\
\hline
\end{tabular}

Published By: 


\begin{tabular}{|l|l|l|l|}
\hline 4. & $\begin{array}{l}\text { The Center for Electronic } \\
\text { Government and Digital Economy } \\
\text { Projects Management }\end{array}$ & 2019 & [25] \\
\hline
\end{tabular}

Fig 1. Institutional Framework for E-Government Development in Uzbekistan.

- An e-Government Development Center has been established under the Ministry, the Center has established strong links with a number of international organizations with extensive experience in this area and has established a systematic exchange of information.[24].

- The Center for Electronic Government and Digital Economy Projects Management has been established under the National Project Management Agency (LBMA) under the Presidential management. In accordance with the Decree of the President of the Republic of Uzbekistan dated January 10, 2019, the main tasks of the Center are: formation of rating on efficiency of ICT implementation in the activities of state administrations, analysis of effective implementation and functioning of e-government and preparation of proposals on improvement of standard-legal framework.[26]

Currently, the single portal of interactive state services www.my.gov.uz, which is an important aspect of the e-government system, is developing rapidly. This portal is connected to all government agencies, including district (city) khokimiyats.[28]

Currently, the portal provides interactive services such as online enrollment for government executives, submitting references for available vacancies in government agencies, submitting online applications for biometric passports, citizens' appeals, consulting, registration of business entities and receiving their reports.[29]

This portal was launched in 2013 and today there are more than 140 public services.
Nowadays, the business registration system was launched in 2017, covering 325 individual businesses and 128 legal entities.

The main task of the Open Data Portal, launched in 2015, is to collect various data for analysis and public services. Apart from the aforementioned systems, there are a number of other functions which will serve as a core for e-government development, including single public service billing; interagency integration platform; database of individuals and legal entities; single identification systems.[30]

As you can see, out of twelve information systems that make up the e-Government architecture in Uzbekistan, seven are working effectively. Currently: retirement; health care; education; justice 2; public administration systems are in the process of production.[31]

In December 2018, Uzbekistan introduced a completely new system for communicating with people, working with appeals, the activities of the Presidential Virtual Reception and Public Reception were organized, which are widely recognized as a unique structure internationally.[32] In a short period of time, these institutions have become an effective mechanism for cooperation between the government and public administration bodies, authorities at all levels, and citizens, allowing them to solve the most pressing problems of the population.

There are more than 2.5 million appeals to the Public receptions addressing to the President of the Republic of Uzbekistan over the last two years.[33]

The regulation.gov.uz web portal, established in Uzbekistan in 2018, began its activity which aims to increase public involvement in the discussion of projects of standard-legal documents.

In the frame of the research were studied effectiveness (Fig 1) and new opportunities (Fig 2) of e-Government Development Center.

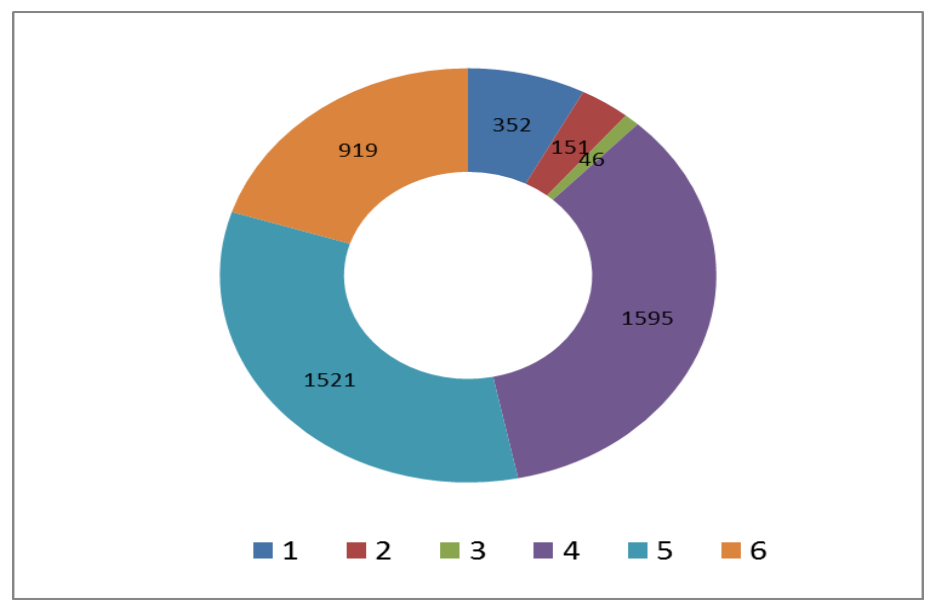

Law of Republic of Uzbekistan

Decree of the President of the Republic of Uzbekistan

Ruling of the President of the Republic of Uzbekistan

Resolution of the Cabinet of Ministers of the Republic of Uzbekistan

Mayor's decision

Order or decision of departments

Fig 1. This diagram shows quantity of new current projects in the open online discussion: (regulation.gov.uz report 2019 december) 


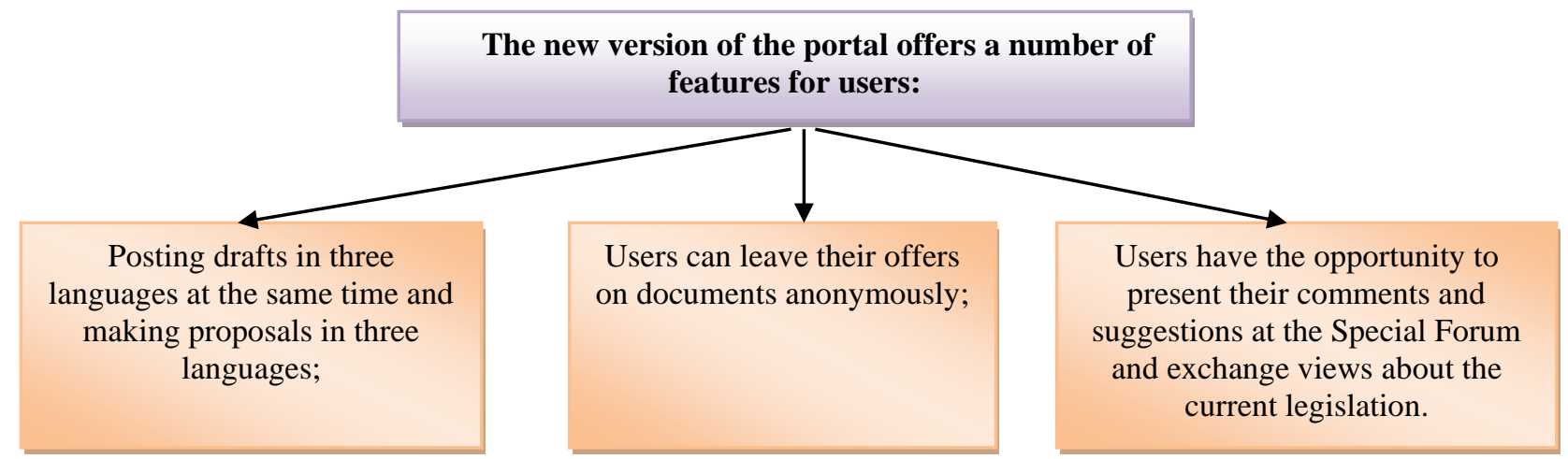

Fig 2. This table shows new opportunities for the people of the "E-government" system.

After a while (from July 2018) a new improved version of the discussion portal of projects of standard-legal documents of the Republic of Uzbekistan has been launched.

In addition, taking into account the current tendency in the legislative process, the Portal has a separate page for placing drafts of law created by the Senate or the Legislative Chamber.

In the nearest future after solving legal and organizational issues, procedure for simultaneous conducting of public discussions of drafts of standard-legal documents and simultaneous departmental agreements and the institution of "cost benefit analysis" on the basis of this Portal are planned to be introduced.[34]

Apart from the aforementioned institutions, there are currently institutes in Uzbekistan, such as the Portal of Public Appeals on New Draft Laws, which, in Mening fikrim[35] (My opinion), allow greater involvement of citizens in governance.

Through such interactive communication between the state and citizens, the possibilities for ensuring transparency of management decisions at all levels of government for the society will be expanded.

An important aspect that allows to increase the effectiveness of civil society in Uzbekistan is the presence of optimal feedback mechanisms, which imply the connection of public authorities with the public in the process of solving certain problems. The dissatisfaction of the population and business in connection with the demolitions of buildings that were observed in July this year in Khorezm, Yangiyul, and Yakkabog confirm the relevance of establishing such a connection. President Sh.Mirziyoev considers the actions of khokims of Khorezm, Kashkadarya and Ferghana regions as a "betrayal".[36]

It should be noted that creation of favorable environment for the population, radical improvement of the quality of public services have been identified as the most pressing issues for the coming years. With a view to coordinating and overseeing the services provided by all government agencies, a new structure was established - the Agency of Public Services under the Ministry of Justice [37].

Currently, there are 201 such centers in each district of the country. They provide more than 100 public services.

Nowadays, 54 standard - legal document drafts related to public services have been developed. This allowed reducing the number of documents submitted by citizens from 155 to 92, and the time required for service - by more than 2 times to a total of 522 days - by 218 days.
It is planned that by 2020 the list of services will be expanded to 160 , in order to create all the conveniences for people.[38]

Some of the organizational work carried out in Uzbekistan to establish an e-Government system:

Within the joint project of UNDP and the Ministry of Development of Information Technologies and Communications of the Republic of Uzbekistan "Promoting Good Governance and Promoting Digital Transformation" an extensive study of international experience in terms of its application to public administration in Uzbekistan is organized.

Specifically, in February 2019, there were discussions on the theme: "Studying Malaysia's experience in the field of administrative reform: conclusions for Uzbekistan".[39]

Or another example. As part of the Uzbekistan-UAE intergovernmental program "Enhancement of Effectiveness of Public Administration System," activities were organized to explore the opportunities of applying UAE's best practices in public administration and intellectual public services, institutional efficiency, innovation and leadership and capacity building.[40]

It is worth noting that such work is not limited with the study of foreign experience, but also measures are being taken to put them into practice. For example, in Mirzo-Ulugbek district in Tashkent, piloting a special procedure for public administration was organized.[41]

It is also worth noting that in recent years Uzbekistan has carried out significant organizational work on strengthening, updating, technical and technological modernization of public administration. 


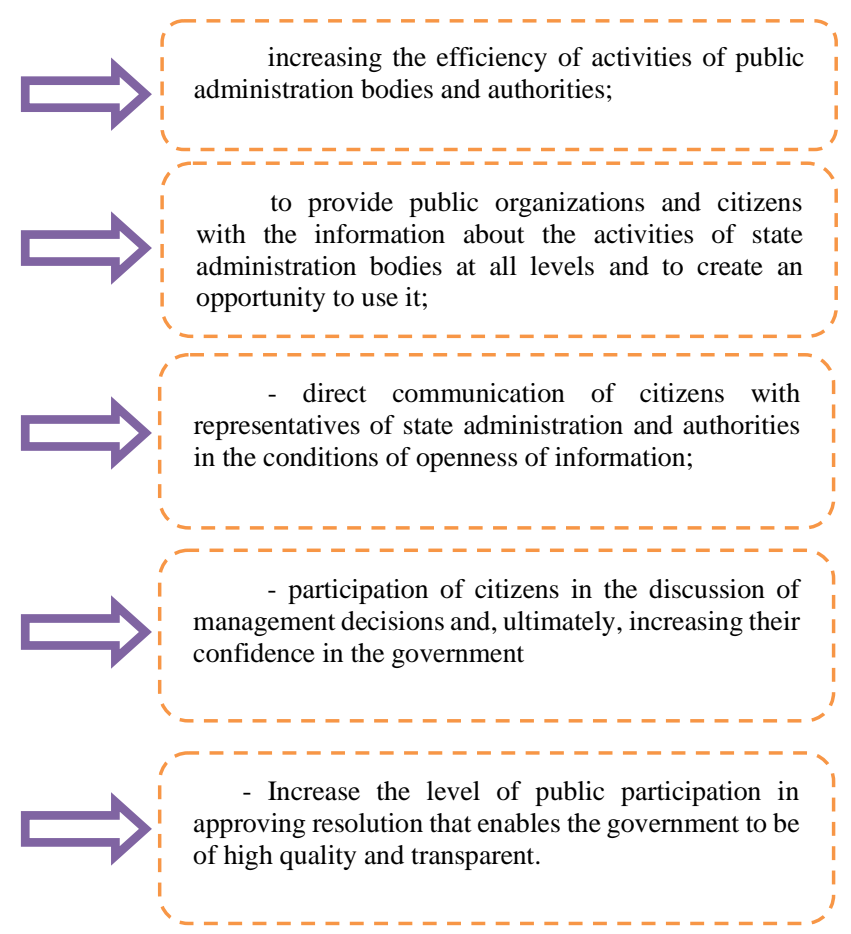

Fig. 3. This drawing shows achievements with the implementation of the "E-government" system in our country in the future.

Free access to information on current processes in the country and its effective use naturally increases the political participation of citizens and creates a need for regular participation in the governance field.

Apart from the above, the introduction of "E-government" system in Uzbekistan creates such additional opportunities:

- more efficient and less costly system of administrative management will be established. According to accounting, that the services provided by government agencies through the e-government system, it is possible to save $\$ 4.5$ billion as a result of providing it online.[41]

In addition, the cost of paper will be drastically reduced. According to data, an employee of the regional khokimiyat uses $26 \mathrm{~kg}$ of paper a year. Taking into account the insufficient natural resources associated with the production of paper in our country, the import of paper, mainly from abroad, it can be seen that the informatization of the services provided by the government can be cut in half in management system. This means that the amount of currency going abroad will be reduced and it will be possible to spend the saved money on other areas of social life.

At the same time, the introduction of e-government system should be considered not only as a practical solution to the problems of public life, but also as an independent idea of radical change in the principles of state governance, as an independent idea of how to modernize existing structures and social relations.

Thus, the transformation of the information space of the modern society leads to the formation of a new system of values, the newest priorities of knowledge and practice. Such values and priorities, in turn, have a significant impact on human behavior in society, on improving the political and economic system, and on the activities of almost all civil society institutions.

At the same time, it is necessary to note that the current political power may have a number of problems as a result of the access to a new resource that did not exist in previous historical periods of social development - an information and communication resource affecting individuals and society. They are as follows:

- The fact that a certain part of society has mastered the ability of information processing and using it effectively, exposes them to the risk of altering the information, propagandizing their ideas and influencing (manipulating) the rest of the community. At the same time, with the advent of e-government and e-democracy, there is a danger of a conflict in the society on the principle of "digital inequality". The degree of coverage of remote and outskirts with mobile communication and inconveniences in the efficient use of the Internet can also lead to "digital inequality".

- Implementation of information and communication technologies in management activities does not give the expected results due to the reluctance of government employees to change their business routines and the constant refusal to accept the need to modernize the existing system. For this reason, the success of e-government depends not only on technical issues, but also on a subjective factor, that is government employees' support for this idea and their sincere desire to implement it.

- As the information infrastructure of the society is created by technologists, the possibility of technocratic principles will prevail in the development of society and in the management of political processes. Therefore, as mentioned above, the role of the "human factor" in the modernization of modern society is increasing.

- The emergence of e-democracy requires the development of personal media, to develop citizens' ability to critically analyze and objectively evaluate the media presented in the information space, to understand the socio-cultural and political laws and specifics of information pluralism and the functioning of democracy of direct use.

- As a result of a dramatic increase in the human ability to influence information processes, there may be a problem of combining individual freedom with a sense of responsibility for their own actions.

- There is also the possibility that the development of information communications can undermine the privacy of people. In recent years, there have been numerous reports in the media about the phone calls of the heads of developed countries, electronic surveillance, electronic control of citizens of the country and the collection of information about their privacy.[43] This situation demonstrates the need to create additional organizational conditions and guarantees for the protection of the rights of users of information technologies, as well as the importance of legal protection of personal information, including privacy, personal and family secrets. The fact that Uzbekistan is paying serious attention to this issue and there are examples given above of legal regulation of relations in this area.[44]

It should be noted that in Uzbekistan there are a number of problems related to state administration reform, implementation of "e-government" system, public awareness of the activities of management administration bodies and wider public involvement in the government approving resolutions.

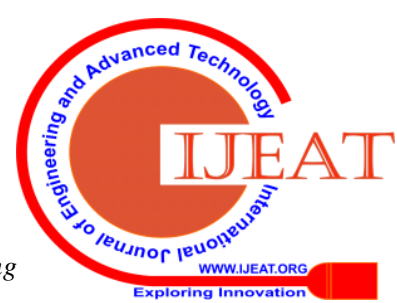


Experience shows that restructuring itself is a challenge for any country. For this reason, it is important for the state to ensure that public participation is an important management mechanism in this process (the process of approving state urges the state to conduct reforms and accelerate that are in the public interest.

Analyzes show that in countries with high levels of public participation in these processes, citizens have higher levels of satisfaction with their lives and less corruption.

Experts of the International Association for Public Participation[45] have developed a model consisting of five stages (public awareness, consultation, engagement, cooperation, giving power to the public) that determine the level of community participation in governance.

Each of the stages differs depending on the level of public authority in approving resolutions or how they influence government resolutions. According to experts of the International Association for Public Participation, Uzbekistan is at the stage of transition from the second stage to the third phase, in other words from giving consultation to involving.[46]

Besides these existed problems in this field, the activity of information service of a number of Republican level organizations, many district and city khokimiyats do not meet the requirements and as well as the insufficient information on the websites of the state and economic organizations, official pages on social networks[47], the failure of the press secretaries to effectively communicate with the media to convey impartial, reliable, prompt, and comprehensive information to the people, the general public and the world community on the essence of large-scale changes in our country, weak participation of press services in social networks and mobile messengers,[48] some leaders are not paying enough attention to working with the press. It is also worth mentioning that up to date there are no information services in about 20 public and economic management bodies, more than 150 district, city and regional khokimiyats.[49]

There is still a lot to do to further improve the public service delivery system.[50]

\section{CONCLUSIONS}

In particular, it is necessary to pay attention to the complete digitization of paper archives in the civil service.

Accordingly, the archival data of all government agencies responsible for the provision of public services will require a gradual digitization until 2025.

As a result of the lack of centralized data processing centers of the state bodies involved in the provision of public services, the following problems arise in the provision of public services:

- electronic exchange of information between government bodies and other organizations that provide public services is not connected to the interagency integration platform;

- more than 30 government agencies have not yet formed departmental databases, so it is impossible to connect them to a single public service platform;

- the digitization of various paper documents and other documents provided by these government agencies remains poor.

One of the main problems in establishing e-government in Uzbekistan is the standard-legal base. Another barrier is the resolutions based on public interests and needs). In its turn, it

lack of a single technological approach to the creation and integration of information systems and resources. In accordance with the infrastructure the e-government infrastructure is not fully developed, this will facilitate the widespread use of modern ICT technologies in the provision of public services and inter-departmental electronic cooperation. Another noticeable problem is the insufficient level of integration of information resources.

As the procedures for the institutions of government administration change dramatically, there is an increasing need to study and reflect on the changes that are taking place.

Such issues further enhance the relevance of in-depth analysis of the prospects for the widespread introduction of e-communications in state administration, and make it a critical issue for the proper assessment of a new type of information space and the creation of the necessary conditions for implementing its positive potential.

\section{REFERENCES}

1. A. S. Duff, in International Encyclopedia of the Social \& Behavioral Sciences: Second Edition(Elsevier Inc., 2015), pp. 83-89.

2. S. Wright, Digital Citizenship: The Internet, Society, and Participation by Karen Mossberger, Caroline J. Tolbert, and Ramona S. McNeal. Journal of Information Technology \& Politics. 5, 262-264 (2008).

3. C. J. Tolbert, K. Mossberger, The effects of E-government on trust and confidence in government. Public Administration Review. 66(2006), pp. 354-369.

4. Abdulla Aripov davlat organlari matbuot xizmatlarining faoliyatini tanqid qildi. Int. https://daryo.uz/k/2019/07/31/abdulla-aripov-davlat-organlari-matbuotxizmatlarining-faoliyatini-tanqid-qildi/

5. "Mualliflik huquqi va turdosh huquqlar to 'g'risida"gi O'zbekiston Respublikasining Qonuni // O‘zbekiston Respublikasi Oliy Majlisi Axborotnomasi", 1996 y., N 9, 136-modda

6. "Shaxsga doir ma'lumotlar to'g'risida" O'zbekiston Respublikasining Qonuni // Qonun hujjatlari ma'lumotlari milliy bazasi, 03.07.2019 y., 03/19/547/3363-son. http://lex.uz/ru/docs/4396419

7. "O`zbekiston Respublikasining jinoyat, Jinoyat-protsessual Kodekslariga hamda O'zbekiston respublikasining ma'muriy javobgarlik to 'g'risidagi kodeksiga o'zgartish va qo'shimchalar kiritish haqida" O'zbekiston Respublikasining Qonuni // Qonun hujjatlari ma'lumotlari milliy bazasi, 09.07.2019 y., 03/19/548/3395-son. http://lex.uz/docs/3831216

8. "O'zbekiston Respublikasi davlat va xo 'jalik boshqaruvi organlarining axborot xizmatlari faoliyatini yanada takomillashtirish chora-tadbirlari to 'g'risida"gi O'zbekiston Respublikasi Vazirlar Mahkamasining Qarori. http://lex.uz/docs/3561681

9. Mirziyoev SH. Milliy taraqqiyot yo 'limizni qat'iyat bilan davom ettirib yangi bosqichga ko'taramiz. -Toshkent: “O'zbekiston” NMIU, 2017. 1-tom. - B.86. 592 bet.

10. Mamlakatni boshqarish yuzasidan endi har kim o'z fikrini bildirishi mumkin. Int. https://kun.uz/57772637

11. Davlat hokimiyati va boshqaruvi organlari faoliyatining ochiqligi to'g'risidagi O'zbekiston Respublikasining qonuni// O'zbekiston Respublikasi qonun hujjatlari to'plami, 2014 y., 19-son, 209-modda; 2017 y., 37-son, 978-modda

12. Elektron hukumat to ' $\mathrm{g}$ 'risidagi $\mathrm{O}^{\prime}$ zbekiston Respublikasining qonuni// O‘zbekiston Respublikasi qonun hujjatlari to'plami, 2015 y., 49-son, 611-modda.

13. "Ijtimoiy sheriklik to'g'risida"gi O'zbekiston Respublikasining Qonuni // O'zbekiston Respublikasi qonun hujjatlari to'plami, 2014 y., 39-son, 488-modda; 2017 y., 37-son, 978-modda, Qonun hujjatlari ma'lumotlari milliy bazasi, 05.01.2018 y., 03/18/456/0512-son

14. «Jismoniy va yuridik shaxslarning murojaatlari to 'g'risida»gi O‘zbekiston Respublikasi Qonunining yangi tahriri // O`zbekiston Respublikasi qonun hujjatlari to'plami, 2017 y., 37-son, 977-modda; Qonun hujjatlari ma'lumotlari milliy bazasi, $30.01 .2018 \mathrm{y}$. 03/18/463/0634-son)

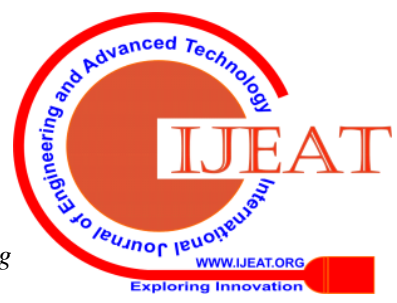


15. "Shaxsga doir ma'lumotlar to 'g'risida" O'zbekiston Respublikasining Qonuni // Qonun hujjatlari ma'lumotlari milliy bazasi, 03.07.2019 y., 03/19/547/3363-son.

16. “O'zbekiston Respublikasining jinoyat, Jinoyat-protsessual Kodekslariga hamda O'zbekiston respublikasining ma'muriy javobgarlik to'g'risidagi kodeksiga o'zgartish va qo"shimchalar kiritish haqida" O‘zbekiston Respublikasining Qonuni // Qonun hujjatlari ma'lumotlari milliy bazasi, 09.07.2019 y., 03/19/548/3395-son.

17. O‘zbekiston Respublikasi Prezidentining 2018 yil 13 dekabrdagi "O'zbekiston Respublikasi davlat boshqaruviga raqamli iqtisodiyot, elektron hukumat hamda axborot tizimlarini joriy etish bo "yicha takomillashtirish chora-tadbirlari to 'g 'risida"gi O'zbekiston Respublikasi Prezidentining 2018 yil 19 fevraldagi PF-5349-son Farmoni. "Aholi muammolari bilan ishlash tizimini yanada takomillashtirish chora-tadbirlari” to 'g'risidagi O'zbekiston Respublikasi Prezidentining farmoni // (Qonun hujjatlari ma'lumotlari milliy bazasi, 18.01.2019 y., 06/19/5633/2496-son). O‘zbekiston Respublikasi Prezidenti huzuridagi loyiha boshqaruvi milliy agentligi faoliyatini yanada takomillashtirish chora-tadbirlari to' $\mathrm{g}$ 'risidagi farmoni. (Qonun hujjatlari ma'lumotlari milliy bazasi, 11.01.2019 y., 06/19/5624/2471-son).O'zbekiston Respublikasi Prezidentining «Aholiga davlat xizmatlari ko'rsatishning milliy tizimini tubdan isloh qilish chora-tadbirlari to'g'risida» 2017 yil 12 dekabrdagi PF-5278-son Farmoni. "Jismoniy va yuridik shaxslarning murojaatlari bilan ishlash tizimini tubdan takomillashtirishga doir chora-tadbirlar to'g'risida"gi O'zbekiston Respublikasi Prezidentining Farmoni // O‘zbekiston Respublikasi qonun hujjatlari to'plami, 2017 y., 1-son, 5-modda.

18. O‘zbekiston Respublikasi Prezidentining 2018 yil 21 noyabrdagi "Raqamli iqtisodiyotni rivojlantirish maqsadida raqamli infratuzilmani yanada modernizatsiya qilish chora-tadbirlari to 'g'risida"gi PQ-4022-son qarori. O‘zbekiston Respublikasi Prezidentining 2018 yil 4 oktyabrdagi "Saylov jarayoniga zamonaviy axborot-kommunikatsiya texnologiyalarini joriy etish chora-tadbirlari to "g 'risida"gi PQ-3961-son qarori. O‘zbekiston Respublikasi Prezidentining 2018 yil 3 iyuldagi "O'zbekiston Respublikasida raqamli iqtisodiyotni rivojlantirish chora-tadbirlari to'g'risida"gi PQ-3832-son qarori (Hujjat matni rus tilida berilgan). O‘zbekiston Respublikasi Prezidentining 2018 yil 14 maydagi "Elektron tijoratni jadal rivojlantirish chora-tadbirlari to 'g'risida"gi PQ-3724-son qarori. O'zbekiston Respublikasi Prezidentining 2018 yil 18 apreldagi "Innovatsion loyihalarni amalga oshirish va idoraviy axborot tizimlarini jadal integratsiyalashuvining tashkiliy chora-tadbirlari to'g 'risida"gi PQ-3673-son qarori. "Normativ huquqiy hujjatlar loyihalarini QHTBT portalida jamoatchilik muhokamasiga qo“yish xususida"gi O‘zbekiston Respublikasi Prezidentining 13.04.2018 yildagi PQ-3666-son qarori. Int. https://www.norma.uz/uz/qonunchilikda_yangi/adliya_vazirligi_nh h_loyihalari_ustida_ishlashda_asosiy_urinni_egallaydi

19. "O'zbekiston Respublikasi davlat va xo'jalik boshqaruvi organlarining axborot xizmatlari faoliyatini yanada takomillashtirish chora-tadbirlari to 'g'risida"gi O'zbekiston Respublikasi Vazirlar Mahkamasining Qarori. http://lex.uz/docs/3561681. O‘zbekiston Respublikasi Vazirlar Mahkamasining 2018-yil 7 martdagi "Aloqa, axborotlashtirish va telekommunikatsiya xizmatlari sifatini yanada yaxshilashga doir chora-tadbirlar to 'g 'risida"gi 185-son qarori. O'zbekiston Respublikasi Vazirlar Mahkamasining 2017 yil 15 sentyabrdagi "O‘zbekiston Respublikasi yagona interaktiv davlat xizmatlari portali orqali elektron davlat xizmatlari ko'rsatish tartibini takomillashtirish chora-tadbirlari to'g'risida"gi 728-son qarori. «O'zbekiston Respublikasi axborot texnologiyalari va kommunikatsiyalarini rivojlantirish Vazirligi hamda O‘zbekiston Respublikasi Axborot Texnologiyalari va Kommunikatsiyalarini rivojlantirish vazirligi huzuridagi Aloqa, axborotlashtirish va telekommunikatsiya texnologiyalari sohasida nazorat bo 'yicha Inspeksiya to 'g'risidagi Nizomlarni tasdiqlash» haqida O‘zbekiston Respublikasi Vazirlar Mahkamasining Qarori // (Qonun hujjatlari ma'lumotlari milliy bazasi, 01.05.2018 y., 09/18/318/1108-son, 25.08.2018 y., 09/18/680/1791-son; 14.05.2019 y., 09/19/397/3123-son) "2016-2018 yillar davrida O‘zbekiston Respublikasida elektron tijoratni rivojlantirish konsepsiyasini tasdiqlash to'g'risida"gi O'zbekiston Respublikasi Vazirlar Mahkamasining Qarori // O‘zbekiston Respublikasi qonun hujjatlari to'plami, 2015 y., 49-son, 612-modda; 2017 y., 29-son, 693-modda; Qonun hujjatlari ma'lumotlari milliy bazasi, 19.12.2017 y., 09/17/992/0426-son.

20. Aholi muammolari bilan ishlash tizimini yanada takomillashtirish chora-tadbirlari” to'g'risidagiO'zbekiston Respublikasi Prezidentining farmoni // (Qonun hujjatlari ma'lumotlari milliy bazasi, 18.01.2019 y., 06/19/5633/2496-son). qo'shimcha chora-tadbirlar to'g'risida"gi PF-5598-son Farmoni. "Axborot texnologiyalari va kommunikatsiyalari sohasini yanada

21. O'zbekistonda aholi muammolari bilan ishlash sohasida yangi tizimga o'tilmoqda.

int.

https://daryo.uz/k/2019/01/21/ozbekistonda-aholi-muammolari-bilan-is hlash-sohasida-yangi-tizimga-otilmoqda/

22. «O'zbekiston Respublikasi axborot texnologiyalari va kommunikatsiyalarini rivojlantirish Vazirligi hamda $\mathrm{O}^{`}$ zbekiston Respublikasi Axborot Texnologiyalari va Kommunikatsiyalarini rivojlantirish vazirligi huzuridagi Aloqa, axborotlashtirish va telekommunikatsiya texnologiyalari sohasida nazorat bo'yicha Inspeksiya to'g'risidagi Nizomlarni tasdiqlash» haqida O'zbekiston Respublikasi Vazirlar Mahkamasining Qarori // (Qonun hujjatlari ma'lumotlari milliy bazasi, 01.05.2018 y., 09/18/318/1108-son, 25.08.2018 y., $\quad$ 09/18/680/1791-son; $14.05 .2019 \quad$ у., 09/19/397/3123-son)

23. “2016-2018 yillar davrida O'zbekiston Respublikasida elektron tijoratni rivojlantirish konsepsiyasini tasdiqlash to 'g 'risida"gi O'zbekiston Respublikasi Vazirlar Mahkamasining Qarori // O‘zbekiston Respublikasi qonun hujjatlari to'plami, 2015 y., 49-son, 612-modda; 2017 y., 29-son, 693-modda; Qonun hujjatlari ma'lumotlari milliy bazasi, 19.12.2017 y., 09/17/992/0426-son.

24. Rasshiryaetsya sotrudnichestvo s Respublikoy Koreya v sfere razvitiya sistemi «Elektronnoe pravitelstvo» // Int: http://ccitt.uz/ru/press_center/news_committee/1205/ - 02 Maya 2014 g.; AKT sohasidagi navbatdagi muvaffaqiyat // Xalq so'zi. - 2014. - 8 noyabr; Ploshadka dlya prodvijeniya innovatsionnix idey // Narodnoe slovo. - 2015. - 2 iyulya; Koreya Respublikasining Axborot jamiyati masalalari bo'yicha milliy agentligi prezidenti O'zbekistonga keldi. Int.https://kun.uz/news/2019/04/12/koreya-respublikasining-axborot-ja miyati-masalalari-boyicha-milliy-agentligi-prezidenti-ozbekistonga-kel di

25. O‘zbekistonRespublikasi Prezidenti huzuridagi loyiha boshqaruvi milliy agentligi faoliyatini yanada takomillashtirish chora-tadbirlari to'g'risidagi farmoni. (Qonun hujjatlari ma'lumotlari milliy bazasi, 11.01.2019 y., 06/19/5624/2471-son) http://lex.uz/docs/4157892

26. O'zbekiston-Koreya forumi: Elektron hukumatni rivojlantirishdagi asosiy yo'nalishlar va muammolar.; Int https://kun.uz/news/2019/03/19/ozbekiston-koreya-forumi-elektron-hu kumatni-rivojlantirishdagi-asosiy-yonalishlar-va-muammolar

27. Qulaylik va tejamkorlik yagona interaktiv davlat xizmatlari portali faoliyatining muhim mezonidir // Xalq so'zi. - 2014. - 30 yanvar.

28. Yagona interaktiv davlat xizmatlari portali ishga tushirilmoqda //Xalq so'zi. - 2013. - 2 iyul.

29. IT-Texnologii: na novom etape razvitiya // Narodnoe slovo. - 2015. - 14 fevral.

30. O‘zbekiston-Koreya forumi: Elektron hukumatni rivojlantirishdagi asosiy yo'nalishlar va muammolar. Int https://kun.uz/news/2019/03/19/ozbekiston-koreya-forumi-elektron-hu kumatni-rivojlantirishdagi-asosiy-yonalishlar-va-muammolar

31. O‘zbekiston-Koreya forumi: Elektron hukumatni rivojlantirishdag asosiy yo'nalishlar va muammolar. Int https://kun.uz/news/2019/03/19/ozbekiston-koreya-forumi-elektron-hu kumatni-rivojlantirishdagi-asosiy-yonalishlar-va-muammolar.

32. O‘zbekiston Respublikasi Prezidentining jismoniy va yuridik shaxslarning murojaatlari bilan ishlash tizimini tubdan takomillashtirishga doir chora-tadbirlar to 'g'risidagi Farmoni. 2016 yil 28 dekabr, PF-4904-son. http://www.lex.uz/acts/3089924.

33. O‘zbekistonda aholi muammolari bilan ishlash sohasida yangi tizimga o'tilmoqda.

Int https://daryo.uz/k/2019/01/21/ozbekistonda-aholi-muammolari-bilan-is hlash-sohasida-yangi-tizimga-otilmoqda/

34. Regulation.gov.uz»ning yangi talqini ishga tushdi »http://protoday.uz/uz/archives/160045 http://protoday.uz/uz/archives/160045

35. "Mening fikrim" maxsus veb-portali yaratildi. Int.http://www.uza.uz/oz/society/mening-fikrim-makhsus-veb-portali-y aratildi-20-04-2018

36. Shavkat Mirziyoev: Farg'ona, Qashqadaryo va Xorazm viloyatlari hokimlarining harakatlari siyosatimga dushmanlik, xiyonat. Int. https://daryo.uz/k/2019/08/03/shavkat-mirziyoyev-fargona-qashqadary o-va-xorazm-viloya

37. tlari-hokimlarining-harakatlari-siyosatimga-dushmanlik-xiyonat/

38. O‘zbekiston Respublikasi Prezidentining «Aholiga davlat xizmatlari ko'rsatishning milliy tizimini tubdan isloh qilish chora-tadbirlari to'g'risida» 2017 yil 12 dekabrdagi PF-5278-son Farmoni. http://lex.uz/docs/3542526

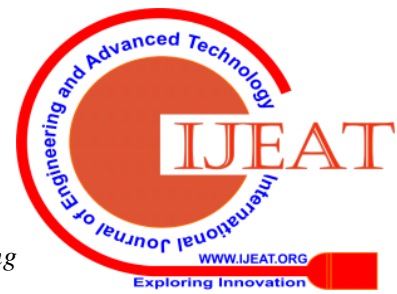


39. "Adliya vazirligi huzuridagi Davlat xizmatlari agentligi tashkil topganiga bir yil bo'ldi” http://uza.uz/oz/society/201-ta-markaz-100-dan-orti-davlat-khizmatlari -5-millionga-ya-13-12-2018.

40. O‘zbekiston davlat boshqaruviga Malayziya tajribasini qo'llash mumkinmi? https://kun.uz/news/2019/02/17/ozbekiston-davlat-boshqaruviga-malay ziya-tajribasini-qollash-mumkinmi

41. O‘zbekiston-BAA: Davlat boshqaruvi tizimini takomillashtirishga oid uch loyiha o'rganildi. Int https://kun.uz/news/2019/05/08/ozbekiston-baa-davlat-boshqaruvi-tizi mini-takomillashtirishga-oid-uch-loyiha-organildi

42. Mirzo Ulug'bek tumanida tajriba tariqasida davlat boshqaruvining alohida tartibini sinovdan o'tkazish boshlandi. Int.https://daryo.uz/k/2018/07/13/mirzo-ulugbek-tumanida-tajriba-tariq asida-davlat-boshqaruvining-alohida-tartibini-sinovdan-otkazish-boshl andi/

43. Kim Nam Sok. Elektron hukumat tizimini joriy qilishning maqsad va vazifalari / Jamiyat va boshqaruv. - 2014. - №4 - - 68-69 betlar.

44. ANB samo doverilo Snoudenu klyuchi ot sekretov // Int. http://www.vesti.ru/doc.html?id=1170044\&tid=103694; Wikileaks SSHA shpionili za pravitelstvom Brazilii// Int http://www.bbc.com/russian/international/2015/07/150704_wikileaks_ usa_brazil; WikiLeaks: pod kolpakom razvedki SSHA pochti ves ofis Merkel// Int.http://www.vesti.ru/doc.html?id=2637385\&tid=82873; Drujeskaya slejka: WikiLeaks publikuet novie dannie o shpionaje SSHA za Fransiey // Int http://www.vesti.ru/doc.html?id=2636832\&tid=82873; Bolshoy brat po-kitayski. http://ru.euronews.com/2017/11/13/china-facial-recognition-bigbrother ; Russkie i kitayskie shpioni proslushivayut chastniy telefon Trampa NYT.

Int. https://www.rbc.ua/rus/news/russkie-kitayskie-shpiony-proslushivayut1540456266.html; OAV: Apple foydalanuvchilarning suhbatlarini tinglaydi. Int. https://kun.uz/ 7193058.

45. "Shaxsga doir ma'lumotlar to 'g'risida" O'zbekiston Respublikasining Qonuni // Qonun hujjatlari ma'lumotlari milliy bazasi, 03.07.2019 y., 03/19/547/3363-son.; "O'zbekiston Respublikasining jinoyat, Jinoyat-protsessual Kodekslariga hamda O‘zbekiston respublikasining ma'muriy javobgarlik to 'g'risidagi kodeksiga o'zgartish va qo 'shimchalar kiritish haqida" O'zbekiston Respublikasining Qonuni // Qonun hujjatlari ma'lumotlari milliy bazasi, 09.07.2019 y. 03/19/548/3395-son. Инт.https://kun.uz/ 7193058; Microsoft has admitted that it listens to user conversations. Int. https://daryo.uz/k/2019/08/15/ microsoft has admitted that it listens to user conversations/

46. https://www.iap2.org/

47. Administrativnaya reforma - chto ona vklyuchaet? Int https://www.gazeta.uz/ru/2019/03/14/administrative-reform/

48. Saida Mirziyoeva: "Axborot xizmatlari tizimini tubdan takomillashtirish lozim!"

http://uza.uz/oz/society/saida-mirziyeeva-akhborot-khizmatlari-tizimin -tubdan-takomi-28-05-2019.

49. Aholini tezkor xabardor qilish masalasiga bee'tibor mansabdor shaxslarga nisbatan chora ko'rilishi mumkin. Int. https://kun.uz/78009680.

50. “Tanqid bor, munosabat yo 'q. Demak hammasi to'g'ri ekan-da?". Bosh vazir Abdulla Aripov tashkilotlar tanqidlarga sukut saqlayotgani haqida gapirdi. Int.: https://t.me/joinchat/AAAAAD63OEHkQHOlfdglMg

51. A.Muminov, O.Muminov, Kh.Polvonov, S.Ktaybekov. To the Way of Informed //International Journal of Recent Technology and Engineering (IJRTE) Volume-8 Issue-4, November 2019. Page No.: 9764-9770.

\section{AUTHORS PROFILE}

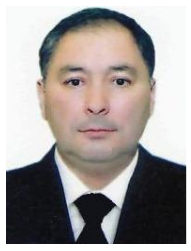

Muminov Alisher, is a Doctor of Political Science, Professor, Dean of the History Department of the National University of Uzbekistan named after Mirzo Ulugbek. His research He has published more than 100 works on political science, culture and history. The national policy of independent Uzbekistan and the ways of its implementation in the spiritual and cultural sphere. His area of interest is Political processes in society, issues of social and economic security and information security. The national policy of independent Uzbekistan and the ways of its implementation in the spiritual and cultural sphere. His area of interest is Political processes in society, issues of social and economic security and information security.

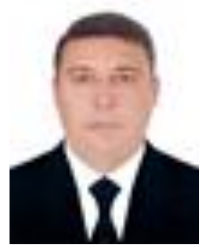

Mavlonov Djurabek, is a Doctor of political sciences, associate professor of National University of Uzbekistan named after Mirzo Ulugbek. He has been teaching several subjects such as - Civil society, theory and practice building a democratic society for more than 15 years. He has published 1 monographs and more than 20 scientific articles.

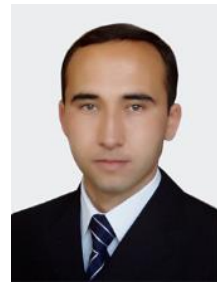

Sokiev Khurshid, is Doctoral candidate (PhD) of National University of Uzbekistan named after Mirzo Ulugbek. He has been teaching several subjects such as - History of philosophy, formal logics for more than 7 years. He has published more than 15 articles on his research theme.

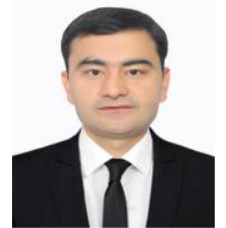

Turgunov Azim, senior lecturer of National University of Uzbekistan named after Mirzo Ulugbek. He has been teaching several subjects such as - social philosophy, social anthropology. He has published more than 10 articles on his research theme. 